\title{
Analysis of Macroeconomics Stability Control of ICI Countries (Indonesia, China, India) Based on Transmission of Monetary Policy through Interest Rate Channel
}

\author{
Annisa Anggreini Siswanto ${ }^{1}$, Ahmad Albar Tanjung $^{2}$, Irsad Lubis ${ }^{3}$ \\ ${ }^{1,2,3}$ Faculty of Economics and Business, Universitas Sumatera Utara, Indonesia \\ Corresponding Author: Annisa Anggreini Siswanto
}

\begin{abstract}
This study aims to analyze variable control of macroeconomic stability based on monetary policy transmission through interest rate channels in Indonesia, China, India (ICI). Variables used in the interest rate are rill interest rates, consumption, investment, gross domestic product, and inflation. This study used secondary data from 2000 to 2019 . The results of the PVECM analysis through the interest rate channel show that the control of economic stability of the ICI country is carried out by investment variables and gross domestic product in the short term, while in the long run it is carried out by consumption, investment and gross domestic product. The results of the IRF analysis are the response stability of all variables is formed in the medium and long term periods. The results of the FEVD analysis show that there are variables that have the greatest contribution in the variable itself either in the short, medium, long term. The results of the interaction analysis of each variable transmission of monetary policy through interest rates can maintain and control the economic stability of the ICI country.
\end{abstract}

Keywords: Interest Rate Channel, Interest Rate, Consumption, Investment, Gross Domestic Product, Inflation.

\section{INTRODUCTION}

Monetary policy is an effort to achieve a sustainable level of economic growth by maintaining price stability. Monetary policy is also taken to achieve the inflation target, resulting in changes in the transmission channels of monetary policy. The pattern of changing and undirected macroeconomic variables will affect the transmission of monetary policy in the long run. In achieving economic stability, monetary policy is also required through macroeconomic fundamentals. To create a strong monetary policy framework, there needs to support from more optimal macroeconomic stability.

The mechanism of transmission of monetary policy through the interest rate channel indicates that monetary policy may affect aggregate demand through changes in interest rates. The development of such interest rates can affect the cost of capital or the cost of capital, which will ultimately also affect the level of investment and consumption. To see the effectiveness of monetary policy and financial system stability in this transmission, it can be monitored with some important parameters that are not directly supervised by the central bank. These parameters include supply elasticity, demand for financial assets (securities), and rill assets.

The phenomenon of problems in this study is by looking at the response of macroeconomic variables to the effectiveness of monetary policy transmission of ICI countries in the research period of 2000 to 2019 as follows: 


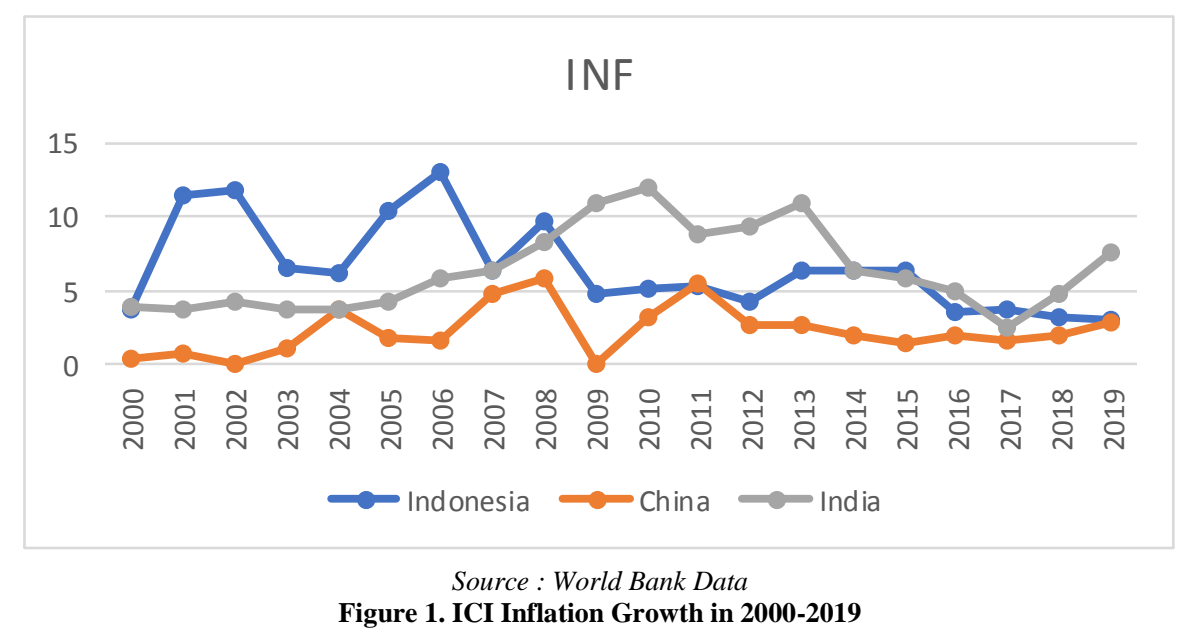

Based on figure 1 , it is known that there is a tendency to occur various fluctuations during the period 2000 to 2019. Indonesia experienced the highest inflation increase in 2006 of 13.11 percent compared to the previous year of 10.45 percent. This increase is due to the rising world oil price and the price of fuel oil in the country. China's highest inflation occurred in 2008 reached 5.92 percent compared to the previous year of 4.81 percent. This is due to the impact of the global economic crisis in the United States. The highest inflation rate in India occurred in 2010 at 11.98 percent compared to the previous year of 10.88 percent. This increase in the inflation rate occurred as a result of policy changes that occurred in the Country of India, thus changing the interest in household consumption.

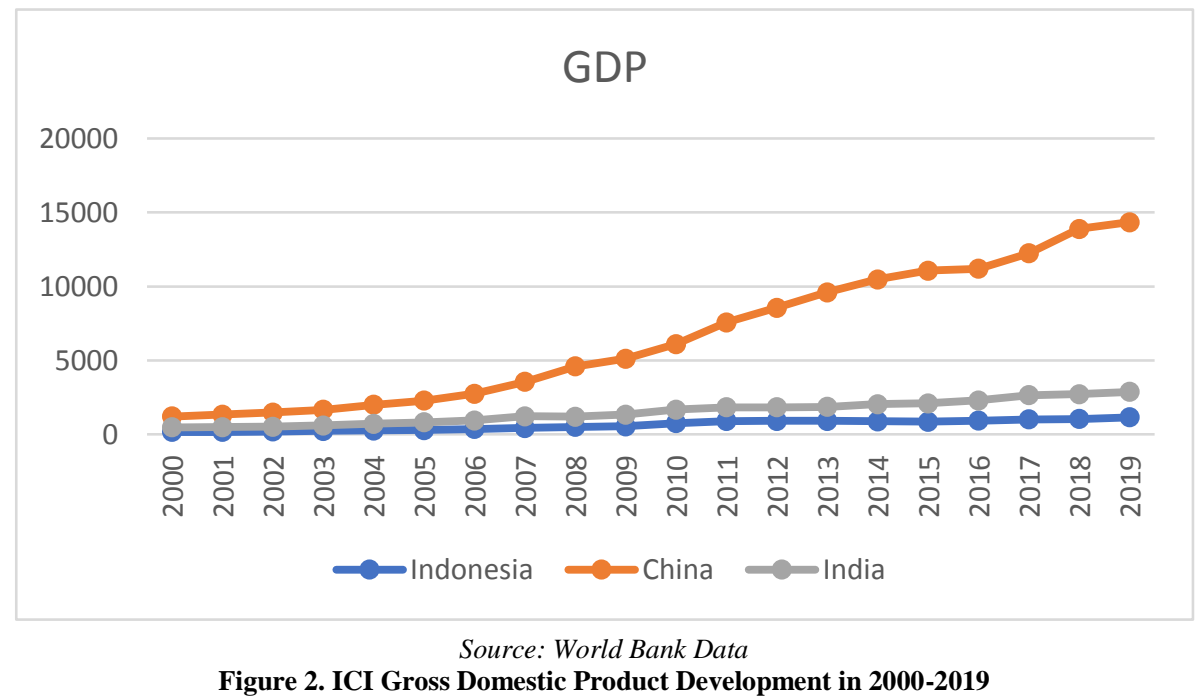

Based on figure 2, it is known that there is a tendency to occur various fluctuations during the period 2000 to 2019. Indonesia Based on figure 2, it is known that there is a volatile trend of gross domestic product from 2000 to 2019 in Indonesia, China, and India (ICI). Gross domestic product in China continues to increase every year. In 2014 GDP growth in Indonesia amounted to 890.81 billion US dollars, there was a decrease in the previous year which reached 912.52 Billion US dollars. The annual increase in the gross domestic product also occurs in India, although the increase is not large. 


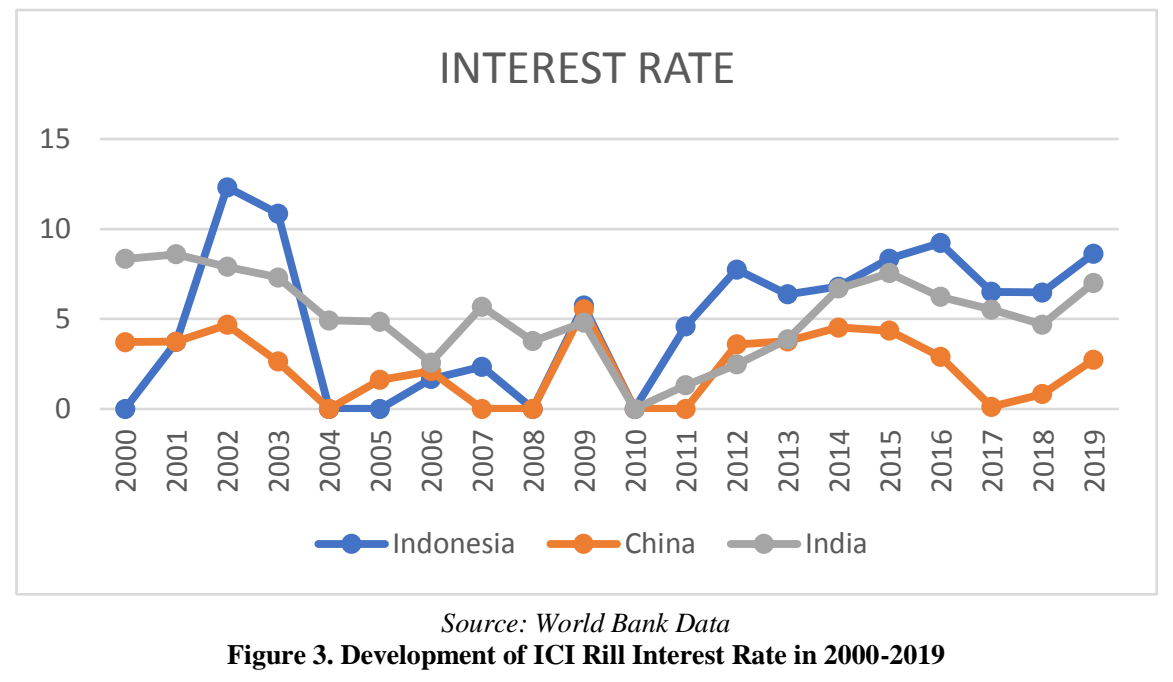

Based on figure 3 it is known that there are fluctuations in various interest rates from 2000 to 2019. Indonesia's highest rill rate occurred in 2002 reached 12.32 percent, this is done to reduce the rate of inflation, if inflation decreases then interest rates will increase. However, the lowest inflation in Indonesia occurred in 2008 to reach -3.58 percent, China experienced the lowest interest rate in 2010 of -1.98 percent, and the Indian state experienced the lowest interest rate in 2008 of -2.30 percent. This is due to the impact of the global economic crisis and rising world oil prices.

Monetary policy transmission aims to examine two important aspects, namely to know the transmission line that has the most effect on the economy as the basis of monetary policy strategy and the second goal to know how strong the influence and length of grace on each transmission line works to influence the rate of change in inflation. In connection with this, it is necessary to conduct a scientific assessment of macroeconomic stability in Indonesia, China, India (ICI) based on the transmission of monetary policy through interest rate channels

\section{LITERATURE REVIEW Inflation}

Inflation is a value where the level of prices of goods and services in general increases. Inflation is one of the monetary events that indicate a tendency to increase the prices of goods in general, which means a decrease in the value of money. The main and only cause that allows this symptom to appear according to the theory of quantity of money in classical mahlab is the occurrence of excess money in circulation as a result of the addition of the amount of money in the community.

According to Keynes in The General Theory of Employment, Interest, and Money, it is stated that inflation is driven by the gap between people's economic ability to desire an item. The Gap is a public demand for goods greater than the amount of money available so there is a price increase, which became known as the inflationary gap.

\section{Interest Rate}

Interest rate is a measure of investment profit that can be obtained by the owner of the capital and is also a measure of the capital costs that must be incurred by the company on the use of funds from the owner of the capital. For investors, deposit interest is profitable because the interest rate is relatively higher than other forms of deposits, also, the deposit rate is relatively less risky. A low-interest policy will encourage people to choose their investment and consumption rather than saving otherwise the policy of increasing the deposit rate will cause people to be happier to save than investing and consume. 


\section{Consumption}

Consumption is the expenditure of goods and services by households. Items include the purchase of durable goods, such as vehicles and equipment as well as nonperishable items such as haircuts and health care. Household spending on education is also included as the consumption of services. Consumption is carried out by two main sectors, namely the government sector (G) and households (C). Government consumption includes public servants' spending, provision of public facilities, and subsidies, while household consumption includes spending on goods and services carried out by a person or household itself.

\section{Investment}

Investment is the purchase of goods that will be used to produce more goods and services. Investment is the amount of the purchase of capital, supplies, and buildings or structures. Sukirno (2004) explained that the investment aims to find a profit where the amount of profit to be obtained becomes the determinant of the level of investment. Some of the main factors that determine the inflation rate the level of profit predicted to be obtained, interest rates, forecasts about the future state of the economy, technological advances, national income levels, and profits earned by companies.

\section{Gross Domestic Product}

Gross Domestic Product (GDP) is the total production of a country. Just calculate the total production of a country regardless of whether the production is done using domestic production factors or not. GDP is a point of economic balance between aggregate demand and aggregate supply. Keynes believes that there is interference from the government to achieve a balanced position, there needs to be control of the economy. The government's goal is to influence the aggregate demand of the community to achieve full employment. GDP in production so that the whole community can buy in the goods market. In the money market, the reason for holding money is for transaction needs, just in case and speculation. The demand for total money is called liquidity preference, the money market is met with the supply of money generating interest rates. The interest rate determines the investor's expenditure in investing to determine the level of aggregate demand. The government's goal is to reduce unemployment to control the market and achieve full employment.

\section{MATERIALS \& METHODS}

This study aims to analyze the ability of monetary policy transmission mechanisms through interest rate channels in controlling the macroeconomic stability of Indonesia, China, India (ICI). This study uses secondary data starting from 20002019 taken through the World Bank Data. This study used the VECM Panel (PVECM) method. The variables used in this study are the variables Interest Rate (SB), Consumption (KON), Investment (INV), Gross Domestic Product (PDB), and Inflation (INF). Some of the steps taken before estimating PVECM model are the Stationarity Test, Optimum Lag Test, and Cointegration Test (Mahyus,2017).

The Standard form of the VECM Panel system to be used in estimation are as follows:

$S B_{t i}=\beta_{10} K O N_{t-p}+\beta_{11} I N V_{t-p}+\beta_{12} P D B_{t-p}+\beta_{13} I N F_{t-p}+\beta_{14} S B_{t-p}+e_{t} 1$ $K O N_{t i}=\beta_{20} I N V_{t-p}+\beta_{21} P D B_{t-p}+\beta_{22} I N F_{t-p}+\beta_{23} S B_{t-p}+\beta_{24} K O N_{t-p}+e_{t}^{2}$ $I N V_{t i}=\beta_{30} P D B_{t-p}+\beta_{31} I N F_{t-p}+\beta_{32} S B_{t-p}+\beta_{33} K O N_{t-p}+\beta_{34} I N V_{t-p}+e_{t} 3$ $P D B_{t i}=\beta_{40} I N F_{t-p}+\beta_{41} S B_{t-p}+\beta_{42} K O N_{t-p}+\beta_{43} I N V_{t-p}+\beta_{44} P D B_{t-p}+e_{t} 4$ $I N F_{t i}=\beta_{55} S B_{t-p}+\beta_{51} K O N_{t-p}+\beta_{52} I N V_{t-p}+\beta_{53} P D B_{t-p}+\beta_{54} I N F_{t-p}+e_{t} 5$

\section{RESULT AND DISCUSSION Panel Unit Root Test}

\begin{tabular}{|c|c|c|c|}
\hline Variable & ADF values & Prob. & Stationary at \\
\hline Suku Bunga & -2.18317 & 0.0145 & level \\
\hline Ln KON & -9.81926 & 0.0000 & $1^{\text {st }}$ Difference \\
\hline Ln INV & -1.88019 & 0.0300 & $1^{\text {st }}$ Difference \\
\hline Ln PDB & -8.84603 & 0.0000 & $1^{\text {st }}$ Difference \\
\hline INF & -9.81926 & 0.0000 & $1^{\text {st }}$ Difference \\
\hline
\end{tabular}

The unit root test was carried out for each variable in the study, interest rate (SB), consumption (KON), investment (INV), gross domestic product (PDB), inflation 
(INF). The unit root test is used the Augmented Dickey-Fuller test approach (ADF).

The result shows that the interest rate variable $(\mathrm{SB})$ is stationary at the level, while the other variables are stationary at the first difference. The next step is determining the optimal lag. The optimal lag test in this study uses the minimum AIC criteria. The optimal lag test result can be seen in the table below.

\section{Optimal Lag}

Table 2. Result of Determining Optimal Lag

\begin{tabular}{|l|l|l|l|l|l|l|}
\hline Lag & LogL & LR & FPE & AIC & SC & HQ \\
\hline 0 & -463.5454 & NA & 207.1350 & 19.52273 & 19.71764 & 19.59639 \\
\hline 1 & -311.0011 & $266.9525^{*}$ & $1.025897^{*}$ & $14.20838^{*}$ & $15.37788^{*}$ & $14.65034^{*}$ \\
\hline 2 & -289.0353 & 33.86393 & 1.205449 & 14.33481 & 16.47889 & 15.14506 \\
\hline 3 & -276.9878 & 16.06339 & 2.264852 & 14.87449 & 17.99316 & 16.05304 \\
\hline 4 & -248.4637 & 32.08968 & 2.350470 & 14.72765 & 18.82090 & 16.27450 \\
\hline \multicolumn{7}{|c|}{ Sources: Research Result }
\end{tabular}

The above lag determination results showed that the lag values of 1 Schwarz Criterion $(15,377)$ and Akaike Information Criterion $(14,208)$ were lower compared to lag 2. The conclusion is that the use of the model at lag 1 is more optimal compared to lag 2 .

\section{Cointegration Test}

Cointegration testing was conducted through the Johansen-Fisher Cointegration Test. Here are the results of the cointegration test:

Table 3. Cointegration Test Result

\begin{tabular}{|c|c|c|c|c|}
\hline \multicolumn{5}{|c|}{ Johansen Fisher Panel Cointegration Test } \\
\hline \multicolumn{5}{|c|}{$\begin{array}{l}\text { Unrestricted Cointegration Rank Test (Trace and Maximum } \\
\text { Eigenvalue) }\end{array}$} \\
\hline Hypothesized & $\begin{array}{l}\text { Fisher } \\
\text { Stat.* }\end{array}$ & & $\begin{array}{l}\text { Fisher } \\
\text { Stat.* }\end{array}$ & \\
\hline No. of CE(s) & $\begin{array}{l}\text { (from } \\
\text { trace test) }\end{array}$ & Prob. & $\begin{array}{l}\text { (from max- } \\
\text { eigen test) }\end{array}$ & Prob. \\
\hline None & 107.2 & 0.0000 & 62.85 & 0.0000 \\
\hline At most 1 & 56.65 & 0.0000 & 40.29 & 0.0000 \\
\hline At most 2 & 23.71 & 0.0006 & 13.75 & 0.0326 \\
\hline At most 3 & 13.78 & 0.0322 & 11.65 & 0.0703 \\
\hline At most 4 & 7.014 & 0.3195 & 7.014 & 0.3195 \\
\hline \multicolumn{5}{|c|}{$\begin{array}{l}\text { * Probabilities are computed using asymptotic Chi-square } \\
\text { distribution. }\end{array}$} \\
\hline
\end{tabular}

Johansen's cointegration test results based on table 3 show that there are 3 equations are integrated at the level of 5 percent significance. So it can be concluded that there is a long-term relationship between the observed variables. So that data analysis can be continued.

\section{Panel VECM Result}

At this stage, the VECM Panel estimation test will establish both short-term and long-term relationships on the observed variables. Here are the observations of VECM Panel estimates:

Table 4. Panel VECM Result

\begin{tabular}{|c|c|c|}
\hline \multicolumn{3}{|l|}{ Short-term } \\
\hline Variable & Coefisien & T-statistic \\
\hline Interest Rate & -0.265252 & -1.25139 \\
\hline Consumption & -1.316032 & -1.66016 \\
\hline Investment & 0.542433 & -2.05517 \\
\hline GDP & 15.16324 & 2.20805 \\
\hline Inflation & 0.817887 & 4.87045 \\
\hline \multicolumn{3}{|l|}{ Long-term } \\
\hline Variable & Coefisien & T-statistic \\
\hline Interest Rate & -0.707274 & -2.85558 \\
\hline Consumption & -2.817407 & -3.13052 \\
\hline Investment & 1.108552 & -5.50861 \\
\hline GDP & 12.35019 & 3.03263 \\
\hline Inflation & 0.458838 & 1.80269 \\
\hline
\end{tabular}

VECM panel test results show that in the short term investment variables have a negative and significant effect in controlling the economic stability of the ICI country. In addition to investment variables in the short term gross domestic product variables positively and significantly in controlling the economic stability of the ICI country. VECM test results based on table 4 show that in the long run variable consumption and interest rates also have a negative and significant negative and significant effect in controlling the economic stability of the ICI country.

Variable Gross Domestic Product has a positive and significant influence in 
controlling the economic stability of the ICI country. An increase in GDP could indicate positive economic growth. GDP is a picture of the state of a country's economy. A stable rate of inflation is a prerequisite for sustainable economic growth and will provide prosperity for individuals.

Table 5. Monetary Policy Interaction in Controlling Stability ICI Country Macroeconomics

\begin{tabular}{|c|c|c|c|c|c|c|}
\hline \multirow{4}{*}{$\begin{array}{l}\text { Variable } \\
\text { Interest Rate }\end{array}$} & \multicolumn{6}{|c|}{ Interest Rate Channel } \\
\hline & \multicolumn{2}{|c|}{ Short-term } & \multicolumn{2}{|l|}{ Medium-term } & \multicolumn{2}{|l|}{ Long-term } \\
\hline & \multicolumn{2}{|l|}{ SB } & INV & INF & INV & INF \\
\hline & \multicolumn{2}{|l|}{100 percent } & 14,51 percent & 14,51 percent & 16,72 percent & 6,65 percent \\
\hline \multirow[t]{3}{*}{ Consumption } & \multicolumn{2}{|l|}{ Short-term } & \multicolumn{2}{|l|}{ Medium-term } & \multicolumn{2}{|l|}{ Long-term } \\
\hline & \multicolumn{2}{|l|}{ SB } & SB & INF & SB & INF \\
\hline & \multicolumn{2}{|l|}{0,83 percent } & 4,56 percent & 2,39 percent & 4,99 percent & 2,47 percent \\
\hline \multirow[t]{3}{*}{ Investment } & \multicolumn{2}{|l|}{ Short-term } & \multicolumn{2}{|l|}{ Medium-term } & \multicolumn{2}{|l|}{ Long-term } \\
\hline & KON & SB & KON & SB & KON & SB \\
\hline & 21,29 percent & 0,64 percent & 30,38 percent & 6,97 percent & 34,89 percent & 6,70 percent \\
\hline \multirow[t]{3}{*}{ GDP } & \multicolumn{2}{|l|}{ Short-term } & \multicolumn{2}{|l|}{ Medium-term } & \multicolumn{2}{|l|}{ Long-term } \\
\hline & SB & KON & SB & INV & SB & INV \\
\hline & 25,57 percent & 1,40 percent & 28,43 percent & 13,20 percent & 29,13 percent & 13,35 percent \\
\hline \multirow[t]{3}{*}{ Inflation } & \multicolumn{2}{|l|}{ Short-term } & \multicolumn{2}{|l|}{ Medium-term } & \multicolumn{2}{|l|}{ Long-term } \\
\hline & SB & KON & SB & PDB & SB & PDB \\
\hline & 15,40 percent & 1,40 percent & 16,38 percent & 7,40 percent & 15,67 percent & 8,10 percent \\
\hline
\end{tabular}

\section{Monetary Policy Analysis for Variable Interest Rate}

Based on the analysis of the interaction of monetary policy variables through the path of interest rates that most affect interest rates in the short term is the interest rate itself. While in the medium and long term the most effective affect interest rates are investment and inflation. The conclusion is that investment and inflation are more effective in controlling interest rates in Indonesia, China, India (ICI) both in the short, medium, and long term. Monetary policy by raising interest rates directly will encourage increased investment, thus boosting gross domestic product. The results of this study are by the research of Bakti and Alie (2018) which states that if there is an increase in interest rates it will increase investment so that gross domestic product output rises. Monetary policy by raising interest rates will also encourage a rise in the rate of inflation in the medium and long term so that it will make individuals more consumptive. The relationship between inflation and interest rates can also be seen in the fisher effect theory that a 1 percent increase in inflation would lead to a 1 percent increase in nominal interest rates.
The relationship between 1 inflation rate and 1 interest rate is called the fisher effect.

\section{Monetary Policy Analysis for Variable Consumption}

Based on the results of monetary policy analysis on consumption, it is known that in the short term the most effective are interest rates, while in the medium and long term the most effective influences on consumption are interest rates and inflation. The conclusion is that rill interest rates and inflation rates are the most effective variables in controlling consumption in Indonesia, China, India (ICI) both in the short, medium, and long term. Monetary policy by raising interest rates will make individuals reduce their consumption to benefit so that individuals reduce their consumption in the present to get greater consumption in the future. The results of this study are by research conducted by Ermon Nuh (2012) which states that if there is an increase in consumption then interest rates will fall and have an impact on the increase in the rate of inflation. This research is also in line with the theory of monetary approach known by Keynes Theory. This theory states that if interest 
rates are low, then individuals will choose to hold the money rather than invest it. In this theory, the policy of holding money is not only just in case but also for a speculative purpose.

\section{Monetary Policy Analysis for Variable Investment}

Based on the results of monetary policy analysis on investment obtained the result that in the short, medium, and long term the most effective in influencing the level of investment is variable consumption and interest rates. The conclusion is that consumption rate and rill interest rate are the most effective variables in controlling investment, the short, medium, and long term in Indonesia, China, India (ICI). Monetary policy by raising interest rates will encourage individuals to save or invest. The results of this study are also supported by Emita research (2013) which states that most of the contributors to economic growth are the level of household consumption, meaning that if there is an increase in the demand for goods and services consumed by households then the producers will increase the amount of production, so it will have an impact on the desire of investors to invest because aka the tone of profit or profit in the future. This research is also by the Classic Theory which states that people's savings are a function of interest rates. Investment is a function of the interest rate, if the interest rate is high then the higher also the desire of the public to save.

\section{Monetary Policy Analysis for Variable GDP}

Based on the results of policy analysis to increase gross domestic product in the short term is influenced by interest rates and consumption. This is in accordance with Keynes theory i.e. $\mathrm{Y}=\mathrm{C}+$ $\mathrm{I}+\mathrm{G}+(\mathrm{X}-\mathrm{M})$. This open economic formula states that the relationship of national income to consumption, if consumption rises it will increase national income. Policies to increase gross domestic product in the medium and long term are most effectively influenced by interest rates and consumption. The conclusion is that monetary policy interaction through the gross domestic product is most effectively influenced by interest rates and consumption in the short term, while in the medium and long term it is influenced by interest rates and investment in Indonesia, China, India (ICI). The results of this study are also by the results of Silvia research (2013) which states that in the long run investment has a positive relationship with gross domestic product. If investment rises, it will also increase gross domestic product. Research from Syahputra (2017) states that gross domestic product has a long-term influence on interest rates. This result is also in line with Harrod-Domar's theory that to raise an economy, capital formation is needed in addition to capital stock. It demands investment as the ability to add goods and services products in the economy as an engine of growth.

\section{Monetary Policy Analysis for Variable Inflation}

Based on the results of the analysis, policies to control inflation in the short term are influenced by interest rates and consumption. The increase in consumption as aggregate demand will encourage price increases and inflation, because increasing consumption indicates high demand from inventories, leading to high prices and inflation. Meanwhile, in the medium and long term policies to control inflation are more influenced by interest rates and gross domestic product. The conclusion is that monetary policy interaction through inflation in the short term is more influenced by interest rates and consumption, while in the medium and long term interest rates and gross domestic product are more effective in influencing the rate of inflation in Indonesia, China, India (ICI). The results of this study are by research conducted by Darmayanti (2014) which states that the rate of inflation influences gross domestic product. Inflation is an indicator in analyzing a country's 
economy, especially closely related to aggregate macroeconomic variables: economic growth, external balance, competitiveness, interest rates, and even income distribution.

\section{CONCLUSION AND SUGGESTION Conclusion}

Based on the results of the analysis and discussion that has been done, it can be concluded as follows:

1. The economic stability of the ICI country can be controlled by the transmission of monetary policy through interest rate channels. Variable interest rates can be used as leading indicators in controlling the economic stability of the ICI country through consumption and investment as leading variables both in the short, medium, and long term

2. Concerning monetary policy, the most important concern is the inflation expectations raised in the community. In addition to the impact of inflation, inflation expectations are generally influenced also by monetary policy adopted by the Central Bank, which is indicated in the development of real interest rates and exchange rates. by the existing theory, if the community is rational enough, they will take action to anticipate the possibility of inflation by spending it in the form of real goods to reduce the risk of inflation is true. Public expectations of inflation (price increases) in turn will encourage a rate increase, and if the rate increase is smaller than the price increase, in real terms the rate of return on financial assets decreases and the decrease will encourage the transfer of wealth to the form of rill assets. If most of the community or even the entire community takes anticipation measures as described above, then such actions will have a very important monetary implication.

\section{Suggestion}

Based on the results of the discussion and conclusions, the suggestions that need to be described by the author are as follows:

1. To control economic stability, the government should increase investment, because the high investment will result in increased investment, the increase will result in increased production capacity of goods and services and then increase labor and then reduce unemployment and have an impact on good economic growth. It is recommended that policymakers also remove barriers to investment inflows and increase their respective absorption capacity to achieve maximum growth effects.

2. Inflation control is carried out by balancing the Inflating Targeting Framework prepared by the central bank of each emerging market country so that monetary policy can achieve the target of controlling economic stability. Recommendations for inflation control policies in emerging market countries are made through consumption and exchange rate stability. Where the movement can affect another macro variable.

\section{Acknowledgement: None}

\section{Conflict of Interest: None}

\section{Source of Funding: None}

\section{REFERENCES}

1. Ekananda, M. 2016. Analisis Ekonometrika Data Panel Edisi 2. Mitra Wacana Media. Jakarta.

2. Gujarati, D. N., Porter, D. C., \& Gunasekar, S. 2012. Basic econometrics. Tata McGrawHill Education.

3. Mankiw, N Gregory. 2006. Principles of Economics, Pengantar Ekonomi Makro. Edisi Ketiga, Alih Bahasa Chriswan Sungkono, Salemba Empat, Jakarta.

4. Miskhin, F. S. 2009. Ekonomi Uang, Perbankan, dan Pasar Keuangan Buku 2 Edisi 8. Salemba Empat. Jakarta. 
Annisa Anggreini Siswanto et.al. Analysis of macroeconomics stability control of ICI countries (Indonesia, China, India) based on transmission of monetary policy through interest rate channel.

5. Sukirno, S. 2004. Makroekonomi Teori Pengantar Edisi Ketiga. Jakarta: Raja Grafindo Persada.

6. Bakti, U., \& Alie, M. S. 2018. Pengaruh Inflasi dan Suku Bunga Terhadap Investasi di Provinsi Lampung Periode 19802015. Jurnal Ekonomi, 20(3), 275-285.

7. Ernita, Dewi, Syamsul Amar, Efrizal Syofyan. 2013. Analisis Pertumbuhan Ekonomi, Investasi, dan Konsumsi di Indonesia. Jurnal Kajian Ekonomi. 1(02): h: 176-193.

8. Nur, E. M., Amar, S., \& Syofyan, E. 2012. Konsumsi Dan Inflasi Indonesia. Jurnal Kajian Ekonomi, 1(1).

9. Silvia, E. D., Wardi, Y., \& Aimon, H. 2013. Analisis Pertumbuhan Ekonomi, Investasi, dan Inflasi di Indonesia. Jurnal Kajian Ekonomi, 1(2).

10. Rusiadi, Ade. N., \& Sanusi, A. 2019. Brici State Monetary Transmission: How Strong Is The Ardl Panel Model Predicting The Final Goal?. Journal Homepage: http://ijmr. net. in, 7(08).

How to cite this article: Siswanto AA, Tanjung AA, Lubis I. Analysis of macroeconomics stability control of ICI countries (Indonesia, China, India) based on transmission of monetary policy through interest rate channel. International Journal of Research and Review. 2021; 8(4): 226-234. DOI: https://doi.org/ 10.52403/ijrr.20210430 